\title{
Application of FLASH in the multi-media teaching courseware making
}

\section{Chunyan Zhang}

Nanchang institute of science \& technology, China

Keyword: Flash; multi-media; teaching courseware; application

\begin{abstract}
The multi-media teaching can vividly and intuitively display the abstract and fuzzy teaching contents, it has a very good effect for foiling and interacting of teaching atmosphere, so the Flash software is the indispensable software in multi-media courseware making. This paper introduced the basic characteristics of Flash, and probed into some problems such as process and method of using Flash to make the multi-media courseware, finally analyzed and summarized the application of Flash in the multi-media teaching courseware.

Compared Flash multi-media teaching courseware and other multi-media teaching softwares, Flash multi-media teaching courseware can more easily to collect many media elements together such as text, images, voice, video and so on, welcomed by majority of teachers. Then how can we produce high quality and excellent teaching courseware? This paper will analyze and discuss the application of Flash in the multi-media teaching courseware.
\end{abstract}

\section{The advantages of Flash in making the multi-media}

Flash is a kind of animation software based on vector graphics, because it can well combine elements such as animation and sound organically together, through makers' skilled use to make the video contents of excellent results, so it has gotten the favour of teachers in the multi-media teaching courseware, mainly because of the Flash has the bellow advantages:

(1) Flash software can make any complex or simple graphic animation, the operation is simple and convenient, it has brought great convenience for teachers to make the multi-media courseware.

(2) The animation making is to use vector graphics to operate, so it takes up little space, broadcast format has a strong compatibility, and it has universality in using.

(3) The documents were made by using Flash, had great stretch space, could be reduced or enlarged indefinitely, the scope of the restricted by hardware is smaller.

(4) Flash due to introducing the concept of "layer", and it has a color gradient tool, can present the three-dimensional effect when making images, and can increase the richness and imagery of multimedia courseware.

(5) Flash supports the import of multiple format file, can import the documents such as text, voice and image, thus it has strong function of the multi-media production.

\section{The application of Flash in the multi-media teaching courseware}

At present, many teachers used the Flash to design multimedia courseware, they only used partial functions of Flash software, and only rest on the use of time frame, scene and components. If we can combine the powerful component design of Flash, it can have the effect of icing on the cake for your multi-media courseware.

In addition, the method of Flash making courseware can be broadly divided into four kinds: scenario method, film method, template method and slide method.

Scenario method

Scenario method is to use the main contents classified into different scenarios. Every question was made into a scene when we made the courseware, then used the command of "goto" to connect. This method is easy to learn.

Film method

Film method is to use the main content classified into different film, the whole courseware only one scenario, each content is made into a film, use the action to link. In this way, the advantage is 
that it can well control the link, particularly suit to the courseware of request return and with menu, the disadvantage is more troublesome.

Template method

This method is only applicable to the above version of Flash MX, this method is simple, all interaction behaviors have been done, it's a pity that the templates provided are less, is far from powerpoint, so this method is not recommended generally.

Slide method

Slide method used in the Flash MX Profession81 2004 and higher version, it can make slide presentation like in PowerPoint, the method is very simple, only need to select the document type as Flash slide presentation when we build a new document. In the actual production of the courseware, we can select one of those methods according to own actual situation, of course also can be mixed with multiple methods.

\section{The making process of Flash multi-media courseware}

Multi-media courseware teaching as a kind of auxiliary teaching software, the main purpose is to promote teaching. The development process of the multi-media courseware teaching generally includes several stages, that is analysis, design, making and so on.

(1) The topic chosen of Flash courseware

Courseware's design must be combined with selected topic, the topic chosen should have a clear teaching goal, can help students to solve the important point and difficult point in the process of learning and the contents which are difficult to describe and understand, give full play to the advantages of multi-media courseware teaching, and improve teaching quality.

(2) The teaching design of courseware

Teaching design is the key in the process of teaching, also in the process of courseware making, teaching design is the key link. Making Multi-media teaching courseware can more intuitively reflect the teaching ideas, give expression to the teachers' teaching experience and personality. Teachers should focus on analysis the teaching contents and teaching objects in the process of making Multi-media teaching courseware, around the teaching target, and adopt appropriate teaching mode to design teaching courseware.

(3) The systematic design of multi-media courseware

Systematic design of multi-media courseware is mainly reflected in how to build the main framework of the courseware, and how to implement the teaching process and teaching mode on the technology. To want the courseware contents rich and vivid, should take more time to the choice of courseware material, pay attention to the accumulation of material at ordinary times, can achieve a better form of cash.

(4) The compilation of multi-media script

Scripts play the role of a link to make, design and use in the process of teaching courseware, courseware making need according to the script, to help complete image design of each frame animation. Each frame was made should be in accordance with the design idea and design requirements of teaching courseware, thus made the design frame to achieve unity and continuity.

(5) The evaluation of multi-media courseware

After the completion of the multi-media teaching courseware, need proceed the commissioning, go through many times of running and debugging, and then save courseware as the file which can run independently.

\section{The problems should be avoided in the courseware making and application of the multi-media Flash}

To apply the multi-media courseware in teaching, can reduce the work intensity of teaching, and also can stimulate students' interest in learning, improve the quality of teaching. Of course, every software has its advantages and disadvantages, there are some problems need makers to pay more attention in the application of making multi-media courseware, and should avoid some problems in 
the concrete making and application.

(1) Hardware facilities couldn't keep up

At present, some remote and poor areas in China, there were a lot of schools hadn't computer and multi-media teaching equipment, hardware facilities couldn't keep up, so it was very difficult to realize multi-media teaching.

(2) The teachers' level wasn't up to par

The computer began to get rapid development was in the 1990's, at that time, due to its high cost, and it was rarely implemented in colleges and universities. It was introdeced into the school education starting from the computer aided teaching, the school started to train a batch of teachers who would teach the course of applying multi-media teaching software, but some teachers were not proficient for using multi-media assisted instruction software, and there were a lot of functions didn't know how to use, therefore it was limited by a certain degree in the process of teaching courseware.

(3) Blindly pursue beauty, showy and not substantial

Some teachers didn't indeed understand the significance of multi-media teaching, excessively pursuited the beauty for courseware in the process of teaching courseware, imported a lot of pictures, animation and sounds in the courseware, tried to attract the students' attention by strong colour and animation effects. Actually otherwise, this courseware was showy and not substantial, distracted the students' attention and deviated the teaching contents and teaching goals.

(4) Communicate with each other had some defects

Flash multi-media teaching courseware has the characteristics of technical, artistry, educational and scientificity, so it will be very rigorous and nervous in the teaching process. But some teachers blindly relied on teaching courseware in the teaching process, and almost had no time for communication and interaction between students. And some teachers excessively pursuited the teaching efficiency in the teaching process, only absorbed in the demonstration courseware, students had no time to digest them, but the frame was switched. This kind of teaching method, ignored the students' feel, and deviated from the purpose of multi-media teaching.

(5) Students usurps the teacher's role, the teacher lost his leading role

Teacher as the leader of the whole classroom, should give full play to the leading role. Teacher should be positive to participate the communication and interaction with students in the process of the demonstration courseware, timely understand the point where students don't know, combine with the courseware content to solve the problem for students, so as to add the enjoyment of the classroom, to stimulate students' learning enthusiasm.

\section{Conclusion}

Due to Flash multi-media teaching courseware has the strong advantages for small size, rich effect, and can run on multiple platforms, so to master this kindly of courseware making technology, can promote the teaching to achieve the effect of get twice result with half effort. There are some problems in the making and application of Flash multi-media courseware, but with the improvement, we believe that Flash multi-media teaching courseware software can get more extensive application.

\section{Reference}

[1] Caiwen Huang. The application of FLASH in the development of the multi-media teaching courseware [J]. Education innovation Herald, 2011 (16).

[2] Yueqi Zeng. Simply analyse the preliminary application study of FLASH in the development of the multi-media teaching courseware [J]. Modern enterprise education, 2013 (34)

[3] Ping Zhang. The application study of FLASH in the development of multi-media teaching courseware [J]. Modern enterprise education, 2013 (10)

[4] Jie Zhang, Wensheng Ye. Several problems should be paid attention to the design of multi-media 
courseware [J]. Modern commercial and trade industry, 2007 (9)

[5] Jun Yan, Xiaowei Zhu. Using the multi-media courseware to optimize classroom teaching [J]. Chinese modern education equipment, 2008 (9) 